\title{
What is new in the Canadian Immunization Guide: November 2016 to November 2018
}

\author{
A Fleurant-Ceelen ${ }^{1}$, M Tunis ${ }^{1}$, A House ${ }^{1}$, on behalf of the National Committee on Immunization \\ $(\mathrm{NACl})^{*}$
}

\begin{abstract}
The Canadian Immunization Guide is an online resource that provides evidence-based recommendations on the use of vaccines and vaccine administration practices to health care providers and public health practitioners in Canada. Its contents are based on the most up-to-date recommendations of the National Advisory Committee on Immunization (NACl) and the Committee to Advise on Tropical Medicine and Travel (CATMAT). The Canadian Immunization Guide (CIG) is frequently updated online in response to new evidence and changing product indications. Between November 2016 and November 2018, new and updated recommendations were published for the chapters on Vaccine Administration Practices, Immunization of Immunocompromised Persons, and Immunization During Pregnancy and Breastfeeding and on seven active vaccines (for cholera and traveller's diarrhea, influenza, hepatitis $A$, hepatitis $B$, herpes zoster, human papillomavirus and pertussis), as well as a recent update on measles post-exposure prophylaxis.
\end{abstract}

Affiliation

${ }^{1}$ Centre for Immunization and Respiratory Infectious Diseases, Public Health Agency of Canada, Ottawa, ON

${ }^{\star}$ Correspondence:

phac.naci-ccni.aspc@canada.ca

Suggested citation: Fleurant-Ceelen A, Tunis M, House A, on behalf of the National Committee on Immunization (NACl). What is new in the Canadian Immunization Guide: November 2016 to November 2018. Can Commun Dis Rep 2018;44(12): 351-5. https://doi.org/10.14745/ccdr.v44i12a06

Keywords: Immunization, $\mathrm{NACl}$, Canada, update, vaccine

\section{Introduction}

The National Advisory Committee on Immunization (NACl) has been providing advice on vaccines to governments and health care professionals in Canada and internationally since 1964 (1). It does this by providing a variety of information products to meet the needs of different audiences. NACl develops detailed and technical products, such as literature reviews and $\mathrm{NACl}$ statements, for immunization experts and policy makers. $\mathrm{NACl}$ also develops summative and translational products, such as statement summaries in the Canada Communicable Disease Report and updates in the Canadian Immunization Guide (CIG), for front line public health and clinical care. Figure 1 provides an overview of $\mathrm{NACl}^{\prime}$ p production process.

CIG has been providing clinically-relevant information on immunization to front line immunization providers since 1979 (2). CIG transformed into an evergreen online format in 2012 (3) and is now updated on an ongoing basis as new recommendations from $\mathrm{NACl}$ are completed. It also includes vaccine and related recommendations from the Committee to Advise on Tropical Medicine and Travel (CATMAT). CIG does not address economic and societal considerations related to immunization; however, it does highlight changes in disease epidemiology, safety signals and vaccine supply issues.
Figure 1: National Advisory Committee on Immunization: Production process

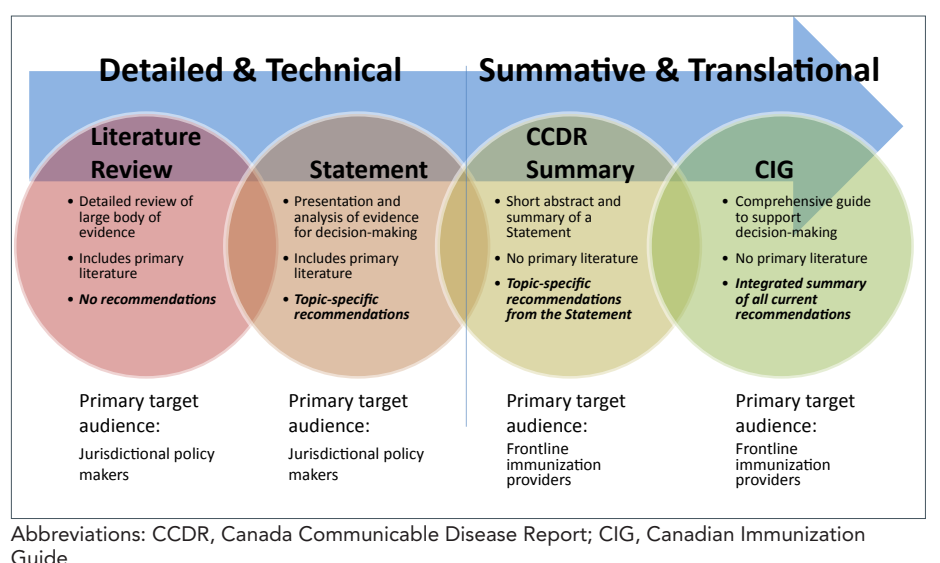
Guide

CIG is divided into five parts: key immunization information; vaccine safety; vaccination of specific populations; active vaccines; and passive immunization.

The purpose of this update is to provide an overview of the changes that have been made to CIG between November 2016 and November 2018. This includes changes to key immunization information, vaccination of specific populations, active vaccines and measles postexposure prophylaxis (PEP). 


\section{Key immunization information}

The chapter on Vaccine Administration Practices (4) was updated. It now has a Needle Selection Guide that emphasizes the importance of selecting needle length for intramuscular injection on a case-by-case basis that includes an assessment of the viscosity of the immunizing agent as well as the recipient's age, weight and muscle mass. The use of filter needles is not recommended as active ingredients such as adjuvants may be filtered out during the injection process. It notes that injections may be provided through a tattoo or a superficial birthmark; however, injections sites with potentially impaired lymphatic drainage should be avoided. There is a new table that provides immunization pain management strategies for clients of all ages. Regarding the combination of contents of multi-dose vials, health care providers are advised to adhere to jurisdictional or organizational policies.

\section{Vaccination of specific populations}

Two chapters were updated: immunization of immunocompromised persons; and immunization during pregnancy and breastfeeding.

Throughout the Immunization of Immunocompromised Persons chapter (5), tables have been included that outline immunization recommendations by vaccine and primary immunodeficiencies, acquired (secondary) immunodeficiencies, transplant recipients/ candidates and HIV-infected persons. New information has been added on defects in innate immunity, criteria for consideration of measles-mumps-rubella and varicella vaccines in those with partial T cell defects, contraindications for live viral vaccines in some types of phagocytic cell defects and immunosuppressive therapy.

The Immunization in Pregnancy and Breastfeeding chapter (6) was updated to reflect the new recommendation to administer pertussis vaccine during every pregnancy between 27 and 32 weeks. It also clearly states that vaccines containing thimerosal are safe in pregnancy and should be used if indicated. Additional considerations during pregnancy have been added for the administration of Rhesus (Rh) immunoglobulin and other blood products and for the administration of the following vaccines: conjugate quadrivalent meningococcal; meningococcal B vaccine; yellow fever; and Japanese encephalitis.

\section{Active vaccines and passive immunization}

Seven active vaccine chapters were updated, along with an update on measles PEP using immune globulin.

\section{Cholera and Enterotoxigenic Escherichia coli (travellers' diarrhea)}

Due to the limited benefits associated with this vaccine, the oral cholera vaccine should no longer be routinely recommended to prevent travellers' diarrhea. CATMAT notes that it may be considered for those who are at highest risk of infection, health complications or serious inconveniences, such as humanitarian workers, health care workers in endemic countries, travellers at high risk of exposure to contaminated water or food, immunocompromised persons and those with chronic illnesses for whom there is an increased risk of serious consequences from travellers' diarrhea. In addition, CATMAT recommends that all other clients follow hand hygiene, food and water safety practices and consider over-the-counter medication for the management of travellers' diarrhea $(7,8)$.

\section{Influenza}

Seasonal influenza vaccine recommendations are updated annually in advance of the influenza season (9).

\section{Hepatitis A}

The recommended dosages for intramuscular immune globulin (IM lg) as pre- and postexposure prophylaxis for hepatitis A have been increased to reflect new product monograph indications (10).

\section{Hepatitis B}

Based on vaccine immunogenicity and safety data, $\mathrm{NACl}$ has revised its recommendation for the dosage of Recombivax $\mathrm{HB} \otimes$ for infants (of hepatitis B-negative mothers) to children less than 11 years of age from $0.25 \mathrm{~mL}$ to $0.5 \mathrm{~mL}$. For children, previously-received doses of $0.25 \mathrm{~mL}$ are still considered valid and do not need to be repeated. For immunocompromised individuals, initial annual monitoring of hepatitis B antibody levels may be considered after primary immunization (11).

\section{Herpes zoster (shingles)}

Following Canadian authorization of the new recombinant herpes zoster vaccine (RZV), Shingrix $®$, NACl now recommends that RZV should be offered to adults 50 years and older without contraindications, including those who have previously received the live zoster vaccine (LZV), Zostavax ${ }^{\circledR}$, at least one year prior. $\mathrm{NACl}$ recommends that individuals without contraindications who have had a previous episode of herpes zoster may be offered two doses of RZV, at least one year after the last episode. When RZV is contraindicated, unavailable or inaccessible, the previously-approved LZV may still be considered for immunocompetent individuals who are at least 50 years old and who have no contraindications. RZV (but not LZV) may be considered in immunocompromised adults who are at least 50 years old on a case-by-case basis (12-14). Two tables have been added to the guidelines that summarize the key considerations for the choice of a herpes zoster vaccine and its administration (12).

\section{Human papillomavirus}

The human papillomavirus (HPV) vaccine, HPV9, is now recommended for immunocompetent males and females who are nine to 14 years old using either a two- or three-dose immunization schedule, while it continues to be recommended using only a three-dose immunization schedule for males and females 15-26 years of age and may be used in those over 26 years of age who are at risk of ongoing exposure. This is similar to HPV2 (females only) and HPV4 vaccines. Any HPV vaccine 
(HPV 2, HPV4, or HPV9 vaccine) should allow at least 24 weeks between the first and last dose in either a two- or three-dose schedule. Immunocompromised individuals should continue to receive the vaccine on a three-dose immunization schedule with at least 24 weeks between the first and last dose of vaccine (15).

\section{Pertussis (whooping cough)}

Recent evidence suggests that infants can effectively be protected against pertussis (whooping cough) through maternal immunization with the tetanus-diphtheria-pertussis (Tdap) vaccine during pregnancy. The Tdap vaccine is now recommended for every pregnancy between 27 and 32 weeks of gestation. When unique patient considerations preclude vaccination during this period, it is possible to offer the Tdap at any time from 13 weeks to the time of delivery (16).

\section{Measles}

New evidence suggests that the previously recommended dosage of immune globulin (lg) no longer provides optimal protection for measles PEP. For NACI has updated recommendations for Ig PEP dosage, indications and routes of administration (17) as follows:

- Immunocompetent individuals six months of age and older who have been exposed to measles and who have no contraindications should be offered a measles-mumpsrubella vaccine within 72 hours of the exposure

- If injection volume is not a major concern, infants younger than six months of age should be given IM lg at a concentration of $0.5 \mathrm{~mL} / \mathrm{kg}$, to a maximum dose of $15 \mathrm{~mL}$, administered over multiple injection sites

- If injection volume is not a major concern, infants six to 12 months old who are identified after 72 hours and within six days of measles exposure should receive IM $\mathrm{lg}(0.5 \mathrm{~mL} / \mathrm{kg})$, to a maximum dose of $15 \mathrm{~mL}$, administered over multiple injection sites

- If injection volume is not a major concern, contacts who are pregnant or immunocompromised can receive IM lg at a concentration of $0.5 \mathrm{~mL} / \mathrm{kg}$, understanding that recipients $30 \mathrm{~kg}$ or more will not receive the measles antibody concentrations that are considered to be fully protective

- In cases where injection volume is a major concern or for recipients $30 \mathrm{~kg}$ or more, intravenous immunoglobulin (IV lg) can be provided at a dose of $400 \mathrm{mg} / \mathrm{kg}$ (17); and

- $\mathrm{NACl}$ does not recommend that susceptible immunocompetent individuals older than 12 months of age receive Ig PEP for measles exposure due to the low risk of disease complications and the practical challenges of administration for case and contact management

A summary of the updated recommendations on the active vaccines is presented in Table 1.
Table 1: Summary of updates on active vaccines and postexposure prophylaxis, November 2016 to November 2018

\begin{tabular}{|c|c|c|}
\hline $\begin{array}{l}\text { Vaccine- } \\
\text { preventable } \\
\text { disease }\end{array}$ & $\begin{array}{l}\text { Previous } \\
\text { recommendation }\end{array}$ & New recommendation \\
\hline $\begin{array}{l}\text { Cholera and } \\
\text { travellers' } \\
\text { diarrhea }\end{array}$ & $\begin{array}{l}\text { Not routinely } \\
\text { recommended for } \\
\text { travellers }\end{array}$ & $\begin{array}{l}\text { May be considered for those } \\
\text { who are at highest risk of } \\
\text { infections, complications or } \\
\text { inconveniences }\end{array}$ \\
\hline Influenza & \multicolumn{2}{|c|}{$\begin{array}{l}\text { New seasonal recommendations are issued every year } \\
\text { in preparation of the upcoming influenza season }\end{array}$} \\
\hline Hepatitis A & $\begin{array}{l}\text { For protection lasting } \\
\text { less than three } \\
\mathrm{months} \mathrm{IM} \mathrm{lg} \text { is } 0.02 \\
\mathrm{~mL} / \mathrm{kg} \text { of body weight } \\
\text { If protection is } \\
\text { required for three } \\
\text { months or longer, } \\
0.06 \mathrm{~mL} / \mathrm{kg} \text { of body } \\
\text { weight should be } \\
\text { administered and } \\
\text { repeated every six } \\
\text { months }\end{array}$ & $\begin{array}{l}\text { IM Ig standard dose with } \\
\text { a dosage of } 0.1 \mathrm{~mL} / \mathrm{kg} \text { is } \\
\text { recommended for household } \\
\text { and institutional hepatitis A } \\
\text { case contacts } \\
\text { For travellers to high risk } \\
\text { areas, prophylactic doses are } \\
\text { as follows: } \\
\text { Up to one month travel }=0.1 \\
\mathrm{~mL} / \mathrm{kg} \\
\text { Up to two months two } \\
\text { months or longer }=0.2 \mathrm{~mL} / \\
\mathrm{kg} \\
\text { Repeat dose of } 0.2 \mathrm{~mL} / \mathrm{kg} \\
\text { every two months }\end{array}$ \\
\hline Hepatitis B & $\begin{array}{l}\text { Recombivax } \mathrm{HB} \otimes \\
\text { dosage for children } \\
0-10 \text { years old of } \\
\text { hepatitis } B \text { negative } \\
\text { mothers: } 0.25 \mathrm{~mL}\end{array}$ & $\begin{array}{l}\text { Recommended dosage for } \\
\text { Recombivax HB increased to } \\
0.5 \mathrm{~mL}\end{array}$ \\
\hline $\begin{array}{l}\text { Herpes zoster } \\
\text { (shingles) }\end{array}$ & $\begin{array}{l}\text { LZV (Zostavax®) } \\
\text { is recommended } \\
\text { for adults } 50 \text { years } \\
\text { and older without } \\
\text { contraindication }\end{array}$ & $\begin{array}{l}\text { The RZV (Shingrix } ®) \text { is } \\
\text { recommended for adults } 50 \\
\text { years old and over without } \\
\text { contraindications, including } \\
\text { those who received LZV at } \\
\text { least one year prior } \\
\text { If RZV is contraindicated, } \\
\text { unavailable or inaccessible, } \\
\text { then LZV may be considered } \\
\text { for immunocompetent } \\
\text { individuals } \geq 50 \text { years of age } \\
\text { without contraindications } \\
\text { RZV (not LZV) may } \\
\text { be considered for } \\
\text { immunocompromised adults } \\
\geq 50 \text { years of age based on a } \\
\text { case-by-case assessment of } \\
\text { the benefits versus risks }\end{array}$ \\
\hline $\begin{array}{l}\text { Human } \\
\text { papillomavirus }\end{array}$ & $\begin{array}{l}\text { HPV9 vaccine } \\
\text { recommended using a } \\
\text { three-dose schedule, } \\
\text { compared to HPV2 } \\
\text { and HPV4 vaccine } \\
\text { which may be used in } \\
\text { a two- or three-dose } \\
\text { schedule in some } \\
\text { populations }\end{array}$ & $\begin{array}{l}\text { HPV9 vaccine now } \\
\text { recommended as a two-dose } \\
\text { or three-dose schedule in } \\
\text { some populations, similar to } \\
\text { HPV2 and HPV4 vaccines }\end{array}$ \\
\hline $\begin{array}{l}\text { Pertussis } \\
\text { (whooping } \\
\text { cough) }\end{array}$ & $\begin{array}{l}\text { Tdap vaccine } \\
\text { should be offered } \\
\text { to pregnant women } \\
\text { during pertussis } \\
\text { outbreaks }\end{array}$ & $\begin{array}{l}\text { Tdap vaccine should be } \\
\text { offered to every woman } \\
\text { during every pregnancy, } \\
\text { ideally between weeks } \\
27 \text { and } 32 \text { of gestation to } \\
\text { protect infants }\end{array}$ \\
\hline
\end{tabular}


Table 1 (continued): Summary of updates on active vaccines and postexposure prophylaxis, November 2016 to November 2018

\begin{tabular}{|c|c|c|}
\hline $\begin{array}{c}\text { Vaccine- } \\
\text { preventable } \\
\text { disease }\end{array}$ & $\begin{array}{l}\text { Previous } \\
\text { recommendation }\end{array}$ & New recommendation \\
\hline Measles & $\begin{array}{l}\text { Dosage: when } \\
\text { indicated, IM Ig at } \\
\text { a concentration of } \\
0.25 \mathrm{~mL} / \mathrm{kg} \text { should } \\
\text { be administered } \\
\text { or } 0.5 \mathrm{~mL} / \mathrm{kg} \text { for } \\
\text { immunocompromised } \\
\text { individuals } \\
\text { Populations: } \\
\text { IM Ig provided } \\
\text { to susceptible } \\
\text { individuals of all ages } \\
\text { presenting between } \\
72 \text { hours and six } \\
\text { days post-exposure; } \\
\text { and provided to } \\
\text { infants under six } \\
\text { months of age, } \\
\text { pregnant women, or } \\
\text { immunocompromised } \\
\text { individuals presenting } \\
\text { anytime up to six days } \\
\text { postexposure }\end{array}$ & $\begin{array}{l}\text { Increased IM Ig dosage: } \\
\text { When indicated, IM Ig at a } \\
\text { concentration of } 0.5 \mathrm{~mL} / \mathrm{kg} \text {, } \\
\text { up to a maximum dosage } \\
\text { of } 15 \mathrm{~mL} \text { where injection } \\
\text { volume is not a concern } \\
\text { Route of administration: IV Ig } \\
\text { can be considered at a dose } \\
\text { of } 400 \mathrm{mg} / \mathrm{kg} \text { when injection } \\
\text { volume is a major concern or } \\
\text { for individuals } \geq 30 \mathrm{~kg} \\
\text { Change to recommended } \\
\text { populations: NACI no longer } \\
\text { recommends that susceptible } \\
\text { immunocompetent } \\
\text { individuals older than } 12 \\
\text { months of age receive Ig } \\
\text { PEP for measles exposure } \\
\text { due to the low risk of } \\
\text { disease complications and } \\
\text { the practical challenges of } \\
\text { administration for case and } \\
\text { contact management }\end{array}$ \\
\hline
\end{tabular}

Abbreviations: HPV, human papillomavirus; Ig, immune globulin; IM Ig, intramuscular immune globulin; IV Ig, intravenous immune globulin; kg, kilogram; LZV, live herpes zoster vaccine; $\mathrm{mg}$, milligram; mL, milliliter; NACl, National Advisory Committee on Immunization; N/A, not applicable; PEP, postexposure prophylaxis; RZV, recombinant herpes zoster vaccine; Tdap, tetanus toxoid, diphtheria toxoid, acellular pertussis; $\geq$, at least

\section{Summary and conclusion}

CIG continues to provide practical, evidence-based recommendations, based on the advice provided by $\mathrm{NACl}$ and CATMAT, to health care professionals to inform front line immunization practices. Summaries of changes are highlighted in Canada Communicable Disease Report from time to time. There is also a list of the changes made to $\mathrm{CIG}$ available online, and this list is updated in close to real time (18). Notices of new $\mathrm{NACl}$ recommendations, statements, $\mathrm{NACl}$ updates and updates to $\mathrm{CIG}$ chapters are also available by subscribing to $\mathrm{NACl}$ and $\mathrm{CIG}$ mailing lists (19).

\section{Authors' statement}

AFC - Writing original draft, review and editing

MT - Review and editing

$\mathrm{AH}-$ Review and editing

\section{Conflict of interest}

None.

\section{Acknowledgements}

NACI members: C Quach (Chair), W Vaudry (Vice-Chair), N Dayneka, S Deeks, P DeWals, V Dubey, R Harrison, M Lavoie, M Salvadori, B Sander, C Rotstein, N Sicard, R Warrington
Liaison representatives: J Brophy (Canadian Association for Immunization Research and Evaluation), E Castillo (Society of Obstetricians and Gynaecologists of Canada), A Cohn (Centers for Disease Control and Prevention, United States), T Cole (Canadian Immunization Committee), J Emili (College of Family Physicians of Canada), C Mah (Canadian Public Health Association), D Moore (Canadian Paediatric Society), A Pham-Huy (Association of Medical Microbiology and Infectious Disease Canada)

Ex-officio representatives: K Barnes (National Defence and the Canadian Armed Forces), G Charos (Centre for Immunization and Respiratory Infectious Diseases [CIRID], Public Health Agency of Canada [PHAC]), J Gallivan (Marketed Health Products Directorate, Health Canada [HC]), J Pennock (CIRID, PHAC), R Pless (Biologics and Genetic Therapies Directorate, HC), T Wong (First Nations and Inuit Health Branch, HC)

\section{Funding}

The work of $\mathrm{NACl}$ is supported by the Public Health Agency of Canada.

\section{References}

1. Desai S, Lsmail SJ, Lerch R, Warshawsky BF, Gemmill I. Canada's National Advisory Committee on Immunization: Celebrating 50 years. Can J Infect Dis Med Microbiol 2015 May-Jun;26(3):126-8. PubMed

2. Public Health Agency of Canada. Canadian immunization guide: Introduction. Ottawa (ON): PHAC; 2017. www.canada. ca/en/public-health/services/canadian-immunization-guide/ introduction.html

3. Public Health Agency of Canada. Canadian immunization guide: Acknowledgements. Ottawa (ON): PHAC; 2016. www. canada.ca/en/public-health/services/canadian-immunizationguide/acknowledgements.html

4. Public Health Agency of Canada. Canadian Immunization Guide: Part 1 - Key Immunization Information; Vaccine Administration Practices. Ottawa (ON): PHAC; [updated 2017]. www.canada.ca/en/ public-health/services/publications/healthy-living/ canadian-immunization-guide-part-1-key-immunizationinformation/page-8-vaccine-administration-practices.html

5. Public Health Agency of Canada. Canadian Immunization Guide: Part 3 - Vaccination of Specific Populations; Immunization of Immunocompromised Persons. Ottawa (ON): PHAC; 2018. www.canada.ca/en/ public-health/services/publications/healthy-living/ canadian-immunization-guide-part-3-vaccination-specificpopulations/page-8-immunization-immunocompromisedpersons.html

6. Public Health Agency of Canada. Canadian Immunization Guide: Part 3 - Vaccination of Specific Populations; Immunization during Pregnancy and Breastfeeding. Ottawa (ON): PHAC; [updated 2016]. www.canada.ca/ en/public-health/services/publications/healthy-living/ canadian-immunization-guide-part-3-vaccination-specific- 
populations/page-4-immunization-pregnancy-breastfeeding. html

7. Public Health Agency of Canada. Cholera and Enterotoxigenic Escherichia Coli (ETEC) Travellers' Diarrhea Vaccine, Canadian Immunization Guide. Ottawa (ON): PHAC; [updated 2017]. www.canada.ca/ en/public-health/services/publications/healthy-living/ canadian-immunization-guide-part-4-active-vaccines/page3-cholera-enterotoxigenic-escherichia-coli-travellers-diarrheavaccine.html

8. Committee to Advise on Tropical Medicine and Travel. Statement on Travellers' Diarrhea. Ottawa (ON); CATMAT; [updated 2015]. www.canada.ca/en/public-health/services/ travel-health/about-catmat/statement-travellers-diarrhea.htm

9. Public Health Agency of Canada. Canadian Immunization Guide Chapter on Influenza and Statement on Seasonal Influenza Vaccine for 2018-2019. Ottawa (ON): PHAC; 2018. www.canada.ca/en/public-health/services/publications/ healthy-living/canadian-immunization-guide-statement-se asonal-influenza-vaccine-2018-2019.html

10. Grifols Therapeutics Inc. Product monograph: GamaSTAN $®$ S/D: Immune Globulin (Human), Solvent/Detergent Treated, Injectable Solution, 15-18\% Protein. 2018. https://pdf.hres. ca/dpd_pm/00043801.PDF

11. Public Health Agency of Canada. Canadian immunization guide: Part 4 - Active Vaccine; Hepatitis B vaccine. Ottawa (ON): PHAC; [updated 2017]. www.canada.ca/ en/public-health/services/publications/healthy-living/ canadian-immunization-guide-part-4-active-vaccines/page7-hepatitis-b-vaccine.html

12. Public Health Agency of Canada. Herpes Zoster (Shingles) Vaccine: Canadian Immunization Guide. PHAC; Ottawa (ON): PHAC; [updated 2018]. www.canada.ca/ en/public-health/services/publications/healthy-living/ canadian-immunization-guide-part-4-active-vaccines/page8-herpes-zoster-(shingles)-vaccine.html
13. Public Health Agency of Canada. National Advisory Committee on Immunization. Updated Recommendations on the Use of Herpes Zoster Vaccine. Ottawa (ON): PHAC; 2018. www.canada.ca/en/services/health/ publications/healthy-living/updated-recommendation s-use-herpes-zoster-vaccines.html

14. Warrington $\mathrm{R}$, Ismail S. NACl. Summary of the $\mathrm{NACl}$ Update on Herpes Zoster Vaccines. Can Commun Dis Rep 2018;44(9):220-5. DOI

15. Public Health Agency of Canada. Canadian Immunization Guide: Part 4 - Active Vaccines; Human Papillomavirus Vaccine. Ottawa (ON): PHAC; [updated 2018]. www.canada. ca/en/public-health/services/publications/healthy-living/ canadian-immunization-guide-part-4-active-vaccines/page9-human-papillomavirus-vaccine.html

16. Public Health Agency of Canada. Canadian Immunization Guide: Part 4- Active Vaccines; Pertussis vaccine. PHAC; Ottawa (ON): PHAC; [updated 2018]. www.canada.ca/ en/public-health/services/publications/healthy-living/ canadian-immunization-guide-part-4-active-vaccines/page15-pertussis-vaccine.html

17. Tunis MC, Salvadori MI, Dubey V, Baclic O; National Advisory Committee on Immunization (NACl). Updated $\mathrm{NACl}$ recommendations for measles post-exposure prophylaxis. Can Commun Dis Rep 2018;44(9):226-30. DOI

18. Public Health Agency of Canada. Canadian immunization guide: Table of updates. Ottawa (ON): PHAC; 2018. www. canada.ca/en/public-health/services/canadian-immunizationguide/updates.html

19. Public Health Agency of Canada. Canadian Immunization Guide update and National Advisory Committee on Immunization - publications mailing list. Ottawa (ON): PHAC; 2018. http://health.canada.ca/en/health-canada/ services/healthy-living/immunization-and-vaccines/ canadian-immunization-guide/subscribe.html 